\title{
Effects of flaxseed on rat milk creamatocrit and its contribution to offspring body growth
}

\author{
Carine Danielle Ferreira Costa Leite, ${ }^{1}$ Gabriela Câmara Vicente, ${ }^{2}$ \\ Akemi Suzuki, ${ }^{2}$ Aline D'Avila Pereira, ${ }^{2}$ Gilson Teles Boaventura, ${ }^{3}$ \\ Ronald Marques dos Santos, ${ }^{4}$ Luis Guillermo Coca Velarde ${ }^{5}$
}

\begin{abstract}
Objectives: To assess the effect of flaxseed on rat milk creamatocrit and its contribution to offspring weight gain during lactation.

Methods: The study was conducted with 22 Lister Hooded rats divided into two groups: Control Group (CG, $\mathrm{n}=11$ ), which received a casein-based diet with $17 \%$ protein, and Flaxseed Group (FG, $\mathrm{n}=11$ ), which received a $25 \%$ flaxseed diet supplemented with $14 \%$ casein, totaling $17 \%$ protein. Food consumption was controlled per individual cage and litter size. Maternal milk creamatocrit and offspring weight variation until weaning age were also evaluated.

Results: $F G$ was similar to $C G$ concerning food intake ( $F G=76.46 \pm 31.87 \mathrm{~g} ; C G=76.7 \pm 33.36 \mathrm{~g} ; \mathrm{p}=0.9613$ ) and equivalent to $C G$ concerning litter size ( $F G=4.94 \pm 2.34 ; C G=5.5 \pm 3.19 ; p=0.435)$. The same was found for milk fat content $(F G=18.4 \pm 4.76 ; C G=15.3 \pm 6.03 ; p=0.204)$ and total energy value $(F G=212.92 \pm 46.4$; $C G=181.1 \pm 60 ; p=0.1964)$. FG was similar to $C G$ both in offspring body weight at weaning ( $F G=37 \pm 6.96 \mathrm{~g}$; $\mathrm{CG}=32.6 \pm 7.5 \mathrm{~g} ; \mathrm{p}=0.1817)$ and in weight gain ( $\mathrm{FG}=31.8 \pm 7.0 \mathrm{~g} ; \mathrm{CG}=27.7 \pm 7.5 \mathrm{~g} ; \mathrm{p}=0.2104)$.
\end{abstract}

Conclusion: A total of $25 \%$ flaxseed promoted an adequate offspring growth.

J Pediatr (Rio J). 2012;88(1):74-8: Flaxseed, casein, rat, creamatocrit, omega-3, body growth.

\section{Introduction}

During pregnancy, the maternal placental and fetal needs for long chain polyunsaturated fatty acids are high. Therefore, a maternal diet with the proper intake of those lipids during gestation and lactation is extremely important. This is especially true for the omega-3 lipids, particularly the docosahexaenoic acid (DHA), once the largest need for this lipid occurs during intrauterine life, mainly during the last trimester of pregnancy and in the pups first months of life, when its largest accumulation in the brain membranes and in the retina occurs. 1,2

Some studies also highlight the functional properties of flaxseed (Linum usitatissimum), which is an excellent source of protein, fiber, and alpha-linolenic fatty acid (ALA) $(n-3)$, presenting 32 to $45 \%$ lipids in its composition, of which 51 to $55 \%$ corresponds to ALA. ${ }^{3,4}$ This compound has protective effects against non-communicable chronic

1. Mestranda, Ciências Médicas, Universidade Federal Fluminense (UFF), Niterói, RJ, Brazil.

2. Estudante de Graduação, Nutrição, UFF, Niterói, RJ, Brazil.

3. Professor associado, Departamento de Nutrição e Dietética, UFF, Niterói, RJ, Brazil.

4. Professor associado, Departamento de Fisiologia, UFF, Niterói, RJ, Brazil.

5. Professor associado, Departamento de Estatística, UFF, Niterói, RJ, Brazil.

No conflicts of interest declared concerning the publication of this article.

Financial support: Fundação de Amparo à Pesquisa do Estado do Rio de Janeiro (FAPERJ) e Programa de Apoio a Planos de Reestruturação e Expansão das Universidades Federais (REUNI).

Suggested citation: Leite CD, Vicente GC, Suzuki A, Pereira AD, Boaventura GT, dos Santos RM, et al. Effects of flaxseed on rat milk creamatocrit and its contribution to offspring body growth. J Pediatr (Rio J). 2012;88(1):74-8.

Manuscript submitted Jul 21 2011, accepted for publication Sep 132011.

http://dx.doi.org/10.2223/JPED.2168 
diseases due to its antioxidant, anti-inflammatory and anticancerous actions, among others. ${ }^{5}$

According to the characteristics described, the objective of this study is to assess the effects of the flaxseed intake during lactation and gestation on the milk creamatocrit of Lister Hood rats and its contribution to offspring body growth during breast-feeding.

\section{Methods}

\section{Ethical aspects}

The experiment was conducted according to the Brazilian Society of Science in Laboratory Animals (Sociedade Brasileira de Ciência em Animais de Laboratório) determinations and was approved by the Animal Research Ethics Committee of the institution, Universidade Federal Fluminense - UFF, under protocol number 00110/09.

\section{Animals}

The study used 22 Lister Hooded rats, in fertile age, from the Laboratory of Experimental Nutrition, of the Department of Nutrition and Dietetics, School of Nutrition, UFF, Niterói, state of Rio de Janeiro, Brazil.

\section{Experimental design}

The rats were divided into two groups: Control Group (CG), comprising 11 animals that had an intake of $17 \%$ casein-based protein; and Flaxseed Group (FG), comprising 11 animals that had an intake of $17 \%$ protein supplemented with $25 \%$ flaxseed, to complete the protein content, and with tert-butylhydroquinone (BHT) antioxidant $(0.014 \mathrm{~g} / \mathrm{kg}$ diet $)$ to prevent the rancidification of the food. This sample size of each group guaranteed a 0.05 significance level and 0.8 power.

All diets were isocaloric and isonitrogenous, balanced and prepared according to the recommendations of the American Institute of Nutrition, ${ }^{6}$ as shown in Table 1.

Rats received the respective experimental diets since mating and were kept in individual cages, with constant temperature $\left(22 \pm 2{ }^{\circ} \mathrm{C}\right)$ and controlled lighting, light-dark cycle $12 / 12 \mathrm{~h}$, receiving water ad libitum. During all the period of the test, which lasted 21 days, litter size per group, food intake and offspring body weight were monitored, twice a week, in a digital MF-3 Filizola ${ }^{\mathrm{TM}}$ scale, with a sensitivity of $0.5 \mathrm{~g}$. Pups were separated from their mothers at 21 days old, weaning age, and mothers received Xylazine anesthetic (20 mg/kg) and Oxytocin (Naox) intraperitoneal injections for milking and milk collection.

Creamatocrit values were measured by the technique developed by Lucas et al.7: after the expressed milk ( $1 \mathrm{ml})$ homogenization, it was heated in water bath at $40{ }^{\circ} \mathrm{C}$ for 10 minutes, centrifuged at $3.500 \mathrm{rpm}$ for 15 minutes, to separate the cream layer from the serum layer, and then, the fat concentration of the milk and its total energy value were calculated.

\section{Statistical analysis}

The data were presented in the mean and standard deviation forms and were assessed with the S-Plus 8.0. Software. The Student $t$ test was used to analyze food intake and creamatocrit, and for the analysis of litter size

Table 1 - Diet formulation ( $\mathrm{g} / 100 \mathrm{~g}$ food) with $17 \%$ protein

\begin{tabular}{lcc}
\hline Components & CG & FG \\
\hline Casein* $^{*}$ Flaxseed $^{+}$ & 20 & 14.2 \\
Starch $^{*}$ & - & 25.0 \\
Sugar§ & 52.95 & 45.83 \\
Mineral Mix* & 10.0 & 10.0 \\
Vitamins Mix* $_{\text {Soybean oil II }}$ & 3.5 & 3.5 \\
Cellulose & 1.0 & 1.0 \\
B-choline* & 7.0 & - \\
Cystine* & 5.0 & - \\
Total & 0.25 & 0.25 \\
& 0.3 & 0.3 \\
\hline
\end{tabular}

$C G=$ control group $; F G$ = flaxseed group .

* Rhosther Indústria e Comércio Ltda.

† ArmaZem Ltda.

‡ Maisena.

§ União.

॥ Liza ${ }^{\circledR}$.

ๆ Macrocel ${ }^{\circledR}$. 
per group and offspring's body weight, the Wilcoxon ranksum test was used, at $p \leq 0.05$ level.

\section{Results}

During gestation and lactation, Table 2 shows that the FG had the same food intake as the CG group ( $p=0.551)$, as well as similar litter size $(p=0.435)$. After the analysis of the creamatocrit, it was also observed that there were no differences between the groups $(p=0.204)$.

At weaning, FG was similar ( $p=0.1817)$ to $C G$ both in body weight (Figure $1 a)$ and in weight gain $(p=0.2104)$ of pups during lactation (Figure $1 \mathrm{~b}$ ).

\section{Discussion}

In the present study, there was no significant difference between the groups in relation to the rats' food intake, and this similarity may be explained by the addition of a small quantity of antioxidant in the flaxseed-based diet, improving palatability and therefore, promoting a better consumption for the animals.

Troina et al. ${ }^{5}$ also found no difference in food intake between the flaxseed and casein experimental groups during lactation, what is in line with the data in this study.

Flaxseed is a rich source of secoisolariciresinol diglycoside (SDG), a plant lignan and precursor of mammal lignans, which acts positively on the human body, helping to prevent and treat cancer. However, in specific periods such as pregnancy, the sensitivity to hormones is increased, so the administration of lignans should be done with caution, because of its phytoestrogen properties. ${ }^{8}$ Studies report that these substances may be related to infertility and hyperestrogenism in some species of animals. ${ }^{9}$

In the present study, both groups were similar in relation to the litter size. Tou et al. ${ }^{10}$ found the same fact for the same experimental groups, as well as Collins et al., ${ }^{11}$ who also found no adverse effects on rats fertility, fetal development and litter size when they fed the rats with flaxseed in high concentrations during pregnancy, lactation and post-lactation.
Fat in maternal milk represents the largest source of energy for the infant, accounting for 40 to $55 \%$ of total energy intake, as well as the lipids represent the best source of energy for the animals, since besides providing metabolic energy, they are also needed to maintain the structure and function of the cell membrane and to provide them with the essential fatty acids. ${ }^{12,13}$

A Offspring body weight at 21 days of age

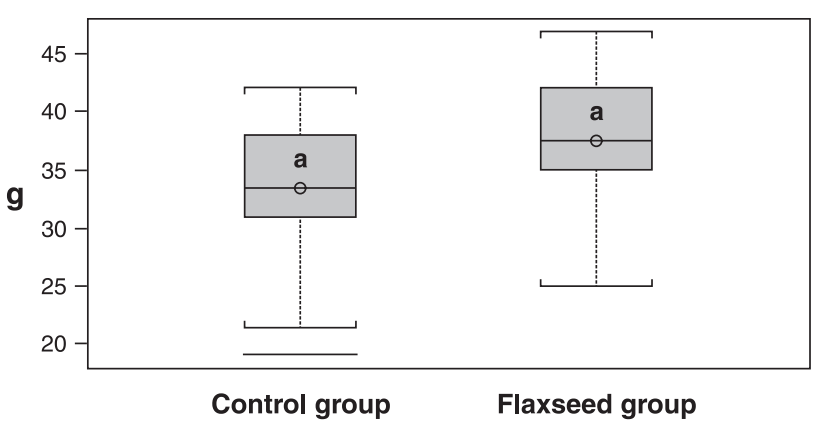

B Offspring weight gain during lactation

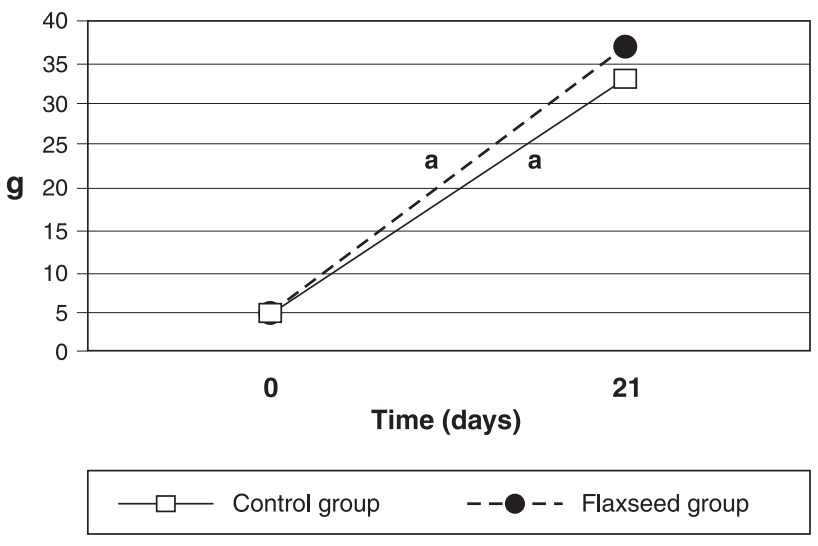

Different letters denote statistical difference at $p \leq 0.05$ level

Figure 1 - Offspring body growth during lactation

Table 2 - Rat food intake, litter size and maternal milk creamatocrit

\begin{tabular}{lcc}
\hline Groups & CG & FG \\
\hline Food intake $(\mathrm{g})$ & $621.3 \pm 97.1^{\mathrm{a}}$ & $646.45 \pm 92.5^{\mathrm{a}}$ \\
Litter size & $5.5 \pm 3.19^{\mathrm{a}}$ & $4.94 \pm 2.34^{\mathrm{a}}$ \\
Fat content of milk (\%) & $15.3 \pm 6.03^{\mathrm{a}}$ & $18.4 \pm 4.76^{\mathrm{a}}$ \\
Total energy value of milk (kcal) & $181.1 \pm 60.0^{\mathrm{a}}$ & $212.92 \pm 46.4^{\mathrm{a}}$ \\
\hline
\end{tabular}

Different superscript letters in the same column mean significant difference $(p \leq 0.05)$ $C G=$ control group; $F G$ = flaxseed group $(n=11 /$ group) 
In this study, breast milk creamatocrit of rats fed with flaxseed proved higher to that of the CG both in fat content and in total energy value, though this superiority was not significant; however, it should be highlighted that the importance lies in the quality of breast-milk fat, especially in the delivery of fatty acids, and not in the amount of fat.

Over the last decades, special attention has been given to the composition and the physiological aspects of the lipid fraction of breast milk, especially to the quality of lipids in maternal diet, as they have a direct influence on the expressed milk fatty acids profile, being crucially important for infant nutrition during lactation. ${ }^{14}$

In the experiment conducted by Almeida et al., ${ }^{15}$ it was verified that the diet supplemented with $25 \%$ flaxseed presented higher concentrations of ALA (C18:3n-3) when compared to the casein-based diet. The same authors also found a significant increase of ALA, besides eicosapentaenoic acid (EPA) (C20:5n-3) and DHA (C22:6n-3) in the milk of flaxseed-fed rats compared to that of casein-fed rats, a fact which demonstrated the conversion efficiency of ALA to DHA and proved that the maternal dietary lipid quality influences the fatty acids profiles in expressed milk.

This finding may suggest that the breast milk of rats fed with a diet supplemented with $25 \%$ of this oilseed might have had an increased intake of $n-3$ fatty-acids in the present study.

At the same time, Visentainer et al. ${ }^{16}$ verified that the diet prepared with flaxseed oil presented higher concentrations of ALA, when compared to diets prepared with other oils, concluding that the flaxseed is the richest oilseed in n-3 fatty-acids, a fact that also suggests that, in the given study, the FG diet might have had a higher concentration of ALA.

In another study on the subject, ${ }^{17}$ it was observed that a diet rich in $n-3$ fatty-acids of 31 Brazilian nursing mothers contributed to elevate the content of such fattyacids in milk.

Silva et al. ${ }^{18}$ also observed that a high consumption of polyunsaturated fatty-acids in eight Brazilian nursing mothers during 10 weeks reflected on a higher content of linolenic acid (n-6) and ALA in milk.

Costa \& Sabarense, ${ }^{19}$ in their review study, found that the milk of Brazilian nursing mothers, compared to that of nursing mothers in other countries, presents a better profile of essential fatty acids and its metabolites (arachidonic acid - n-6; e DHA), besides a lower quantity of trans and saturated fatty acids, what led them to conclude that Brazilian maternal nutrition is possibly the main factor contributing to this.

Growth is a dynamic and continuous process that occurs from conception until the end of life and is expressed by the increase in body size. ${ }^{20} \mathrm{~A}$ dietary shortage, especially in protein, causes a reduction in food consumption, leading to a decrease in body weight and a delay in weight gain. ${ }^{21}$ In the present study, it can be observed that pups fed by mothers which received flaxseed diets had greater body weight and weight gain, revealing that this seed is an excellent source of protein and fat, although this superiority is not statistically significant.

According to Almeida et al., 22 in $100 \mathrm{~g}$ of flaxseed, there are $396 \mathrm{kcal}, 109$ from protein and 287 from lipids, and such values were considered excellent for a plant source. In the study performed with 21-day-old pups from the same breed, but from the Wistar lineage, it was observed that the animals from mothers who also received a diet supplemented with $25 \%$ flaxseed presented lower body weight than the CG animals ( $C G=47.31 \pm 4.72 \mathrm{~g} ; \mathrm{FG}=42.69 \pm 3.06 \mathrm{~g})$, as well as a lower weight gain $(C G=41.45 \pm 4.81 ; F G=36.55 \pm 3.82) .^{23}$ These results are distinct from the present experiment; both in body weight ( $C G=32.6 \pm 7,5 \mathrm{~g} ; \mathrm{FG}=37 \pm 6.96 \mathrm{~g}$ ) and in weight gain $(C G=27.7 \pm 7.5 ; F G=31.8 \pm 7.0)$.

Soares et al. ${ }^{24}$ found that by using flaxseed as the only protein source during offspring growth, without adding any animal protein, there was a lower weight gain for the flaxseed-fed group when compared to the casein-fed group; a fact which led them to considerate this oilseed of low protein quality, because it interfered negatively in the animals body growth.

Leite et al., 25 however, considered this oilseed a good source of protein, once it promoted normal growth for the pups, even though they found lower body growth for animals which received flaxseed-based diets compared to those receiving casein-based diets during growth period.

Therefore, it can be concluded that flaxseed proved to be a good source of protein and lipids, promoting adequate growth in animals during lactation. However, more studies should be performed on the omega- 3 fatty acids transfers from flaxseed to breast milk.

\section{References}

1. Silva DR, Miranda Júnior PF, Soares EA. A importância dos ácidos graxos poliinsaturados de cadeia longa na gestação e lactação. Rev Bras Saude Matern Infant. 2007;7:123-33.

2. Dangat KD, Kale AA, Joshi SR. Maternal supplementation of omega 3 fatty acids tomicronutrient-imbalanced diet improves lactation in rat. Metabolism. 2011;60:1318-24.

3. Figueiredo MS, de Moura EG, Lisboa PC, Troina AA, Trevenzoli IH, Oliveira $\mathrm{E}$, et al. Flaxseed supplementation of rats during lactation changes the adiposity and FGucose homeostasis of their offspring. Life Sci. 2009;85:365-71.

4. Santos FL, Azeredo VB, Martins AS. Efeito do fornecimento de ração complementada com semente de linhaça sobre os macronutrientes e colesterol em tecidos de camarões da Malásia (Macrobrachium rosenbergii). Cienc Tecnol Aliment. 2007;27:851-5. 
5. Troina AA, Figueiredo MS, Moura EG, Boaventura GT, Soares LL, Cardozo LF, et al. Maternal flaxseed diet during lactation alters milk composition and programs the offspring body composition, lipid profile and sexual function. Food Chem Toxicol. 2010;48:697-703.

6. Reeves PG, Nielsen FH, Fahey CG Jr. AIN-93 purified diet of laboratory rodents: final report of the American Institute of Nutrition ad hoc Writing Committee on the Reformulation of the AIN-76A rodents diet. J Nutr. 1993;123:1939-51.

7. Lucas A, Gibbs JA, Lyster RL, Baum JD. Creamatocrit: simple clinical technique for estimating fat concentration and energy value of human milk. Br Med J. 1978;1:1018-20.

8. Saarinen NM, Thompson LU. Prolonged administration of secoisolariciresinol diFGycoside increases lignan excretion and alters lignan tissue distribution in adult male and female rats. $\mathrm{Br}$ J Nutr. 2010;104:833-41.

9. Zimmerman SA, Clevenger WR, Brimhall BB, Bradshaw WS. Diethylstilbestrol-induced perinatal lethality in the rat. II. Perturbation of parturition. Biol Reprod. 1991;44:583-9.

10. Tou JC, Chen J, Thompson LU. Flaxseed and its lignan precursor, secoisolariciresinol diFGycoside, affect pregnancy outcome and reproductive development in rats. J Nutr. 1998;128:1861-8.

11. Collins TF, Sprando RL, Black TN, Olejnik N, Wiesenfeld PW, Babu US, et al. Effects of flaxseed and defatted flaxseed meal on reproduction and development in rats. Food Chem Toxicol. 2003;41:819-34.

12. Tinoco SM, Sichieri R, Moura AS, Santos FS, do Carmo MG. Importância dos ácidos graxos essenciais e os efeitos dos ácidos graxos trans do leite materno para o desenvolvimento fetal e neonatal. Cad Saude Publica. 2007;23:525-34.

13. Hayashi C, Soares CM, Matsushita M, Galdioli EM, Cocito IC. Desempenho e características de carcaça do escargot francês (Helix aspersa maxima) alimentado com rações contendo diferentes óleos vegetais. Cien Rural. 2004;34:231-7.

14. Innis SM. Human milk: maternal dietary lipids and infant development. Proc Nutr Soc. 2007;66:397-404.

15. Almeida KC, Teles Boaventura G, Guzmán-Silva MA. Influence of omega-3 fatty acids from the flaxseed (linum usitatissimum) on the brain development of newborn rats. Nutr Hosp. 2011;26:991-6.

16. Visentainer JV, Gomes ST, Hayashi C, Santos-Junior OO, Silva $A B$, Justi $K C$, et al. Efeito do tempo de fornecimento de ração suplementada com óleo de linhaça sobre a composição físico-química e de ácidos graxos em cabeça de tilápias do Nilo (Oreochromics niloticus). Cienc Tecnol Alimen. 2003;23:478-84.
17. Patin RV, Vítolo MR, Valverde MA, Carvalho PO, Pastore GM, Lopez FA. The influence of sardine consumption on the omega-3 fatty acid content of mature human milk. J Pediatr (Rio J). 2006;82:63-9.

18. Silva MH, Silva MT, Brandão SC, Gomes JC, Peternelli LA, Franceschini SC. Fatty acid composition of mature breast milk in Brazilian women. Food Chem. 2005;93:297-303.

19. Costa AG, Sabarense CM. Modulação e composição de ácidos graxos do leite humano. Rev Nutr. 2010; 23:445-57.

20. Brasil. Ministério da Saúde. Saúde da criança: acompanhamento do crescimento e desenvolvimento infantil. Cadernos de Atenção Básica. n.11. Brasília; 2002. p. 3-25.

21. Lima JG, Oliveira LM, Lachat JJ, Dal-Bo CM, Almeida SS. Comparison of the effects of lab chow and casein diets based on body and brain development of rats. Braz J Med Biol Res. 1993;26:1069-76.

22. Almeida KC, Boaventura GT, Guzmán-Silva MA. A linhaça (Linum usitatissimum) como fonte de ácido a-linolênico na formação da bainha de mielina. Rev Nutr. 2009;22:747-54.

23. Cardozo LF, Soares LL, Chagas MA, Boaventura GT. Maternal consumption of flaxseed during lactation affects weight and hemoFGobin level of offspring in rats. J Pediatr (Rio J). 2010;86:126-30.

24. Soares LL, Pacheco JT, Brito CM, Troina AA, Boaventura GT, Guzmán-Silva MA. Avaliação dos efeitos da semente de linhaça quando utilizada como fonte de proteína nas fases de crescimento e manutenção em ratos. Rev Nutr. 2009;22:483-91.

25. Ferreira Costa Leite CD, Calvi Lenzi de Almeida K, Guzmán-Silva MA, Azevedo de Meneses J, Teles Boaventura G. Flaxseed and its contribution to body growth and brain of Wistar rats during childhood and adolescence. Nutr Hosp. 2011;26:415-20.

Correspondence:

Carine Danielle Ferreira Costa Leite

Rua Tiradentes, 107/506 - Ingá

CEP 24210-510 - Niterói, RJ - Brazil

Tel.: + 55 (21) 2629.9860, +55 (21) 8387.0222

E-mail: carinecleite@gmail.com 